DOI: 10.31392/NPU-nc.series14.2019.27.15

УДК 378.147:784(477) (510)

Хайе Лян

\title{
Сутнісні характеристики та особливості вокальної підготовки студентів у вищих педагогічних закладах України і Китаю
}

\begin{abstract}
Висвітлюються особливості вокальної підготовки майбутніх учителів музики у педагогічних закладах вищої освіти Китаю та України. В результаті порівняльного аналізу з'ясовано, що на зміст вокальної підготовки студентів у ЗВО Китаю впливають: художні та естетичні характеристики національного світосприйняття, своєрідність ладово-ментальної основи китайського мелосу, фонетикоутворювальна, декламаційно-артикуляційна специфіка вокально-мовленнєвої культури китайців, орієнтованість на майбутню вокально-виконавську, а не вокально-педагогічну діяльність. Вокальна підготовка учителів музики в українських педагогічних вишах базується на традиціях національної співацької культури та європейських школах вокального виконавства, має системно-структурний характер та здійснюється у науково-теоретичному, організаційно-методичному та художньовиконавському напрямках.
\end{abstract}

Ключові слова: вокальна підготовка; майбутній учитель музики; музично-педагогічна освіта.

Актуальність дослідження. Протягом останніх десятиріч у світі спостерігається суттєве посилення ролі освітньо-мистецького діалогу країн i народів 3 метою формування полікультурного простору для взаємозбагачення та обміну прогресивними ідеями й досвідом, науково-технічної кооперації, створення і реалізації різноманітних проектів тощо. В той самий час зберігаються тенденції розвитку і дбайливого збереження культурної, зокрема мистецької спадщини різних етносів, народів.

Мета статті визначається тим, що в контексті активізації україно-китайських відносин особливий інтерес викликає проблема вивчення та осмислення специфіки організації і реалізації вокальної підготовки фахівців музично-педагогічного профілю в цих країнах, 3 урахуванням національно-історичних, духовно-практичних, освітньо-соціальних аспектів іiі спрямування. Знання студентами-іноземцями особливостей вокальної підготовки допомагає їм краще адаптуватися до умов, вимог та змісту навчально-освітньої діяльності.

Виклад основного матеріалу. Культурний і суспільно-економічний розвиток Китаю проходив таким чином, що професійна вокальна освіта 3'явилась лише близько ста років тому. Незважаючи на це, академічний спів швидко зайняв першорядні позиції разом із традиційним китайським мистецтвом. У 1978 році у КНР було оновлено та осучаснено систему музичної освіти, рішенням деяких державних установ іiі було приведено у відповідність до потреб і соціальних замовлень суспільства, збільшено кількість вищих навчальних закладів музичного, музично-педагогічного профілю, підвищено якість теоретичної і методичної підготовки майбутніх фахівців.

Разом з тим за останній період зросла кількість китайських студентів, що здобувають професійну музичну освіту у багатьох країнах Європи, світу. Ця тенденція, з одного боку, обумовлюється зростанням ролі глобальних інтеграційних процесів у сферах наукововиробничого, гуманітарного, культурно-освітнього, інформаційно-технологічного, творчомистецького взаємообміну та співробітництва. 3 іншого боку, у КНР і сьогодні відчувається гостра нестача педагогічних кадрів, незважаючи на те, що все більше китайських студентів навчаються у європейських університетах, зокрема у закладах вищої освіти (ЗВО) України.

Наприкінці XX століття було створено трирівневу систему професійної музичної освіти (середній, вищий та післядипломний - науковий рівні), а вищим навчальним закладам було дозволено самим визначати та обирати необхідні для якісної вокальної освіти навчальні дисципліни, розробляти плани і програми. Сьогодні у КНР професійну вокальну освіту студенти здобувають у: 1) консерваторіях або інститутах музики (підготовка в галузі класичного академічного вокалу або народного китайського співу); 2) музичних факультетах педагогічних університетів (підготовка вчителів музики, педагогів з вокалу); 3) університетах 
3 переважно теоретичною підготовкою науковців, у тому числі у галузі історії та теорії музичного навчання.

Проблемам вокальної підготовки студентів музично-педагогічного профілю присвячені наукові дослідження Лю Цин, Ван Пейюань, Лі Чуньпен, Хуан Чанхао, Лі Чуцай, Лю Сян-ю, Сю Хайлінь, Хо Інін, Шу Сіньчен, Гу Інь, Сунь Цзінань, Сіньюй Нуан, Яо Вей та ін. Визначаючи національні досягнення в галузі музично-педагогічної освіти, учені висвітлюють певні проблемні питання, які потребують нагального вирішення. Серед них:

- недостатня профілізація освіти та переорієнтація іiі 3 музично-виконавського на музично-педагогічний напрямок;

- потреба у створенні умов для формування високої музичної та загальної культури студентів;

- недостатнє впровадження передових, інноваційних технологій навчання, зокрема європейського походження;

- вирішення питання розширення та оновлення змісту психолого-педагогічного блоку дисциплін, а також удосконалення методичної підготовки студентів.

Значний вплив на зміст та спрямованість вокальної підготовки студентів у педагогічних університетах Китаю мають традиції національного солоспіву, специфіка ладового устрою музики, індивідуально-ментальні особливості будови організму китайських співаків, а також специфіка мовленнєвої культури китайців.

Протягом багатьох століть у Китаї сформувались власні, доволі специфічні співацькі традиції, що були обумовлені: своєрідною мелодикою китайських пісень, яким притаманні інтонаційна гнучкість, виразність, широкий діапазон, оздоблення мелізмами, швидкі зміни темпу, ритму, руху мелодії; важливим значенням поетичного тексту та його нерозривною єдність з музичним змістом, а також жестом і танцем; чітким розподілом пісенної культури на жанри i, відповідно, способи (техніки) виконання вокальної музики (народна пісня, Пекінська опера, драма-декламація, сучасні академічні твори тощо).

Організація вокальної підготовки студентів у національних педагогічних університетах Китаю базується на принципі урахування і творчого використання вказаних особливостей розвитку пісенної культури. Крім того, значний вплив на спрямування вокальної підготовки здійснює існуюча практика викладання музики у загальноосвітніх школах Китаю. Вона передбачає, що основним змістом музичних занять з учнями виступає слухання музики та навчання співу. Традиційно склалося так, що саме сприйняття музики, а не музична творчість складає основу навчально-освітньої діяльності китайських школярів. Хоча сьогодні педагоги все частіше включають елементи музичної імпровізації, виконавства, самостійної діяльності учнів у навчально-виховний процес [8].

Студенти музично-педагогічних відділень китайських університетів вивчають історію і теорію вітчизняного і світового музичного мистецтва, музично-теоретичні дисципліни, оволодівають навичками гри на музичному інструменті, навчаються вокальної майстерності. Наукову і практичну основу вокальної підготовки, як правило, складають розроблені у СРСР (у тому числі і Україні) та західних країнах теорії та методики навчання класичного i народного співу.

Порівняльний аналіз дозволяє висвітлити особливості організації та проведення вокальної підготовки майбутніх учителів музики у ЗВО України. Вокальна підготовка студентів музично-педагогічного профілю в Україні виступає важливою складовою цілісної (комплексної) системи професійної освіти майбутнього вчителя музичного мистецтва. Аналіз науково-педагогічних джерел (Л. Василенко, Н. Можайкіна, Ю. Мережко, Т. Овчаренко та ін.) доводить, що в основу вокальної підготовки покладені теоретичні положення й методичні напрацювання представників вітчизняної музично-педагогічної освіти, досвід європейської практики навчання вокалу за академічною (класичною) системою, а також використання надбань національно-вокальної спадщини й традицій народного співу. 
Українська музична педагогіка стоїть на позиції, що ефективність майбутньої педагогічної діяльності учителя музики забезпечується високим рівнем розвитку співацьких навичок і вмінь, системною сформованістю спеціальних мистецьких знань, методичних компетенцій. Таким чином, вокальна підготовка студентів у ЗВО педагогічного профілю здійснюється за визначеними напрямками: науково-теоретичним, організаційно-методичним, художньо-виконавським. Їх реалізація обумовлюється характером і змістом фахової діяльності майбутніх учителів музики в українській школі.

Науково-теоретичний напрямок (складова) вокальної підготовки студентів, зокрема, передбачає:

- забезпечення глибокими i системними музично-історичними, теоретичними i методичним знаннями в галузі вокального мистецтва та виконавства, організації процесу вокального навчання школярів;

- озброєння студентів актуальною інформацією в галузі анатомії та фізіології щодо будови і функціонування співацького апарату учнів різного віку, особливостей мутації та проблем розвитку дитячого голосу;

- формування навичок самостійної науково-теоретичної (дослідницької) діяльності в галузі теорії та методики вокального навчання;

- оволодіння студентами співацьких традицій українського народу та використання їх у власній фаховій діяльності.

Організаційно-методичний напрямок вокальної підготовки студентів передбачає формування методичної компетентності, зокрема, в галузі вокального навчання й виховання підростаючого покоління. Зміст організаційно-методичного блоку вокальної підготовки студентів націлює на глибоке засвоєння практичних способів і засобів (методик) розвитку співацького голосу школярів, реалізації методичних умінь та навичок роботи з голосовим апаратом учнів в залежності від рівня розвитку й підготовленості школярів до вокального навчання.

Володіння методиками вокального навчання школярів дозволяє добирати та використовувати найбільш оптимальні методи і прийоми вокальної роботи з учнями; сприяє встановленню активних міжособистісних і творчо-виконавських зв'язків 3 підопічними; націлює вчителя на пізнання індивідуальних психологічних та художніх особливостей розвитку школярів 3 метою його моніторингу, проектування та досягнення запланованих результатів; стимулює на постійну методичні самоосвіту, удосконалення себе як вчителя і співака.

Методична підготовленість студента в галузі індивідуальної вокальної роботи з учнями відображає сформованість вокально-методичної, педагогічної та комунікативної культури; розуміння специфіки індивідуальних видів і форм організації вокально-творчої, художньоестетичної діяльності школярів; наявність умінь добирати художньо-привабливий, педагогічно-доцільний вокальний репертуар в залежності від особистісного і музичного розвитку школярів; спрямованість виявлення творчих здібностей учнів засобами вокальної діяльності та ін.

Вокально-виконавська діяльність є невід'ємною і надзвичайно важливою складовою фахової діяльності вчителя музики. Вокальне виконавство супроводжує вчительську працю у класній та позакласній роботі зі школярами. Виступаючи в якості соліста-виконавця, педагога-вокаліста, організатора дитячого ансамблю або хору, вчитель повинен демонструвати високу співацьку культуру, володіти технічними і художніми засобами вокального виконавства.

«Вокально-виконавські вміння та навички майбутніх педагогів-музикантів, - вказує Хуан Чанхао, - виявляються під час втілення художнього образу вокального твору в ході ілюстрування на уроках або під час концертного виступу, через використання тембрального забарвлення співацького звуку, міміки, жестів, виразності вокального мовлення, емоційності виконання, інтерпретаторських умінь вокаліста» [5, с. 173]. 
Зміст художньо-виконавського компоненту вокальної підготовки вчителів музики полягає у розвитку професійних співацьких умінь і навичок роботи над вокальними творами різних жанрів і стилів та передбачає, зокрема:

- оволодіння студентами навичок самостійної роботи з вокальним репертуаром (читання нот $з$ листа, транспортування, робота над диханням, музичною інтонацією, фразуванням тощо);

- розвиток здатності емоційно-виразно та артистично доносити до учнів, слухачів музично-образний, естетичний зміст вокальних творів, створювати їх художню інтерпретацію;

- формування власної (оригінальної) манери вокального виконавства.

Починаючи зі студентства, вокально-виконавська майстерність вчителя формується протягом всього життя i фактично відображає процес особистісного i професійного становлення й зростання в галузі вокального мистецтва, вокально-художньої діяльності.

У світлі проблематики даного дослідження доцільно прослідкувати суттєві відмінності і спільні риси у технологіях вокального навчання китайських та українських студентів 3 урахуванням таких компонентів, як: постановка виконавського дихання, використання резонаторів, співацька дикція та артикуляція, фонетика і художні особливості вокального звуковидобування.

Як свідчить практика вокального навчання, і в Україні, і в КНР педагогіка приділяє важливе значення постановці правильного виконавського дихання, проте тут існують суттєві технологічні відмінності. У відповідності до співацьких декламаційних традицій в Китаї співакам рекомендують дихати не дуже глибоко і швидко, а також легко і вільно, з опорою на нижню черевну частину тулуба. Українська культура народила особливий тип мелосу, що відрізняється широтою фразування й розвитку, а тому потребує використання «довгого» виконавського дихання. У цьому українська вокальна школа має багато спільного 3 європейською практикою бездоганного виконання «бель канто». Китайський тип вокального дихання орієнтований на донесення, перш за все, літературного змісту твору, принаймні у виконанні класичних китайських творів, зразків Пекінської опери. Гортанно-грудний спів китайських народних виконавців вимагає великого напруження дихальної системи й роботи зв'язок. Тому вокальне навчання передбачає тренування чіткого контролю та економії дихання, а також дозованого навантаження голосового апарату співаків.

Європейська і китайська практики вокального навчання великого значення надають ефективному використанню резонаторів. Українська вокальна педагогіка за європейською традицією привчає студентів використовувати весь комплекс резонаторів організму, що призводить до формування глибокого, рівномірного та красиво забарвленого звучання голосу. Китайські викладачі орієнтують на застосування переважно головного та носового резонаторів, які надають особливої «металевої» сили і пронизливого тембру як чоловічим, так і жіночим голосам. Проте сьогодні вокальні педагоги в Китаї достатньо ефективно використовують методики розвитку усіх резонаторів (грудного, носового, черепного та ін.) співаків.

Важливе питання функціонування дикції та артикуляції звуків під час співу стоїть в центрі уваги українських та китайських вокальних педагогів. Мовленнєві особливості китайців пов'язані з активною роботою органів ротової порожнини, особливо язика та губ. Спеціальна увага приділяється чіткому вимовлянню приголосних на початку слів. Українська та європейська традиція вимови натомість потребує чіткого, повнозвучного й плавного звучання, а вербальні особливості тексту значно поступаються якісній вокалізації, естетиці художньої «подачі» голосу тощо.

Окремі особливості вокального звуковидобування у співацькій практиці різних народів пов'язані з фонетичними якостями мови. Дослідники проблем китайської музики вказують на наявність тісного взаємозв'язку між національним мелосом та мовою китайського народу, а також підкреслюють значення смислових емоцій як основних виразників інтонаційно- 
вербального змісту в китайських музичних творах. У зв’язку з цим вокальна підготовка вчителя музики повинна враховувати глибинну єдність цих компонентів та навчати студентів емоційно-художньому інтонуванню музики.

Слов'янські мови, на відмінну від китайської, відрізняються іншим співвідношенням у словах голосних i приголосних, створюють більше можливостей для вокального розспівування, голосоведіння. Переважання у мові голосних «и», «о», «е» та «а» впливає на якість кантилени, сприяє виявленню різноманітних динамічних градацій, демонстрації усіх художньо-виконавських можливостей. У вокальній підготовці вчителів музики на ці особливості завжди звертається увага, у роботі зі студентами застосовуються спеціальні фонетичні вправи, завдання на розвиток чіткого, розчленованого вокального вимовлення.

Висновки. Проведений аналіз особливостей змістового наповнення вокальної підготовки майбутніх учителів музики у педагогічних ЗВО України і Китаю дає можливість виокремити найбільш специфічні відмінності та одночасно сформулювати узагальненні принципи іiі організації та реалізації в умовах національної системи музично-педагогічної освіти.

Таким чином, порівняльний аналіз вокальної підготовки майбутніх учителів музики в Україні та Китаї дає можливість висвітлити найбільш перспективні підходи до удосконалення iii організації, покращення теоретичного та методичного забезпечення, а також створити сприятливі умови для використання досягнень цих країн 3 метою обміну міжнародним музично-освітнім досвідом та активізації творчо-мистецьких відносин.

\section{Література}

1. Арчажникова Л. Г. Профессия - учитель музыки. М. : Просвещение, 1984. 111 с.

2. Василенко Л.М. Підготовка студентів музично-педагогічних факультетів до професійнопедагогічної діяльності в контексті їх вокально-методичного навчання. Соціалізація особистості: зб. наук. праиь Т. 14. К., 2007. С. 136-142.

3. Лі Чуньпен. Методика формування вокальної компетентності майбутніх учителів музики: дис. ... канд. пед. наук: 13.00.02 - теорія і методика музичного навчання. НПУ ім. М.П. Драгоманова. - К., 2013. 203 c.

4. Мережко Ю.В. Формування навичок самостійної роботи майбутніх учителів музичного мистецтва на заняттях з постановки голосу. Науковий часопис НПУ імені М.П. Драгоманова. Серія 14. Теорія і методика мистецької освіти. Вип. 26. К. : НПУ ім. М.П. Драгоманова, 2019. С. 75-82.

5. Хуан Чанхао. Специфіка вокального навчання майбутніх вчителів музичного мистецтва. Науковий часопис НПУ імені М.П. Драгоманова. Серія 14. Теорія і методика мистецької освіти. Вип. 26. - К. : НПУ ім. М.П. Драгоманова, 2019. С. 169-175.

6. Цинь Чень Особливості формування готовності до саморозвитку майбутнього учителя музики у процесі вокально-хорового навчання. Науковий часопис НПУ імені М.П. Драгоманова. Серія 14. Теорія і методика мистеиької освіти. Вип. 16 (21). - К.: НПУ ім. М.П. Драгоманова, 2014. С. 99-104.

7. Ян Бохуа. Музыкальное воспитание в общеобразовательных школах современного Китая: автореф. дис. ... канд. пед. наук : 13.00 .02 - теория и методика обучения и воспитания. СанктПетербург, 2009. 24 с.

8. Яо Вей. Проблемы развития вокального профессионального образования в современном Китае [Электронный pecypc]. Режим доступа: http://cyberleninka.ru/article/n/problemy-razvitiyaprofessionalnogo-obrazovania-v-sovremennom-kitae/

\section{Про автора:}

Хайе Лян, кандидат педагогічних наук, лектор, Хуанганський нормальний університет (438000, Хуанган, провінція Хубей, Китай); ORCID: 0000-0001-9944-1866, 417689733@qq.com

\section{Essential characteristics and specifics of students' vocal training in Ukrainian and Chinese higher pedagogical institutions}

\section{Haiye Liang}

The article under consideration refers to the issue of revealing the specifics of managing and providing the prospective Music teachers' vocal training in Chinese and Ukrainian higher pedagogical institutions. The comparative analysis results show that the students' vocal training syllabus in Chinese higher institutions is 
predetermined by: artistic and aesthetic characteristics of national world outlook; specifics of modal and mental fundamentals of Chinese melos; phonetic-constituting, declamation and articulation characteristics of the Chinese's vocal and speech culture; focus on the prospective vocal and performance vs. vocal and teaching activity. Vocal education in Ukrainian pedagogical institutions is based on the traditions of national singing culture and European vocal performance training schools.

The goal of the article is predetermined by the fact that within the context of facilitating the UkrainianChinese interaction, there appears an issue of interpreting the specifics of managing and implementing Music and Pedagogy major experts' training in the aforementioned countries, alongside with considering the national and historical, mental and practical, socio-educational aspects of its focus. The foreign students' grasp of vocal skills characteristics promotes their better adjustment to the conditions (factors), requirements and content of the training activity.

Recently, the number of Chinese students obtaining professional Music education in most European countries has grown considerably. This tendency, on the one hand, is predetermined by increasing the role of global integration processes within science and manufacturing, humanitarian, culture and educational, information and technological, artistic interchange and cooperation domain; on the other hand, China is still experiencing the lack of teaching human resources, notwithstanding an increasing number of Chinese students studying in Europe, in particular, in Ukrainian higher institutions.

When defining the national achievements within the field of Music and Teacher Training Education, Chinese scholars reveal certain key issues requiring immediate resolution, i.e.: insufficient education profiling and its re-directing from Music and performance focus to Music and Pedagogy one; the need of creating the environment for shaping the students' music and general culture; the non-efficient implementation of advanced and innovation teaching technologies, in particular, of European background; solving the question of expanding and updating Psychology and Pedagogy syllabi, as well as perfecting the students' methodological background.

Substantial impact on the content and focus of students' vocal training in Chinese pedagogical universities is implied via national solo singing traditions, the specifics of modal composition of music, alongside with speech culture characteristics.

In accordance with European tradition, Ukrainian Vocal Pedagogy is targeted at the students' implementing the whole complex of body resonators, which contributes to shaping the profound, consistent and well-flavoured voice production (sounding). Chinese lecturers focus the students on implementing chiefly head-register and nasal voice (resonators) securing the specific metal force and raucous timbre for both men's and women's voice; however, nowadays Chinese Vocal teachers implement quite effectively the methodology of shaping all the singers' resonators (chest, nasal, cranial ones, and others).

Ukrainian and Chinese Vocal teachers lay special emphasis on an important issue of diction functioning and sounds articulation. The Chinese's speech specifics are related to the persistent work of the mouth cavity organs, especially the tongue and the lips. Special attention refers to distinct consonants articulation at the beginning of words. Ukrainian and European speech traditions, in their turn, require a distinct, full-toned (sonorous) and smooth sounding, while the verbal text specifics make a considerable concession to efficient vocalisation alongside with the aesthetics of the artistic voice presentation, etc.

Keywords: vocal training (background); the prospective Music teacher; Music and Pedagogical (teacher training) education.

\section{References}

1. Archazhnikova L.G. Professiya - uchitel muzyki. M. : Prosveshenie, 1984. 111 s. [in Russian]

2. Vasilenko L.M. Pidgotovka studentiv muzichno-pedagogichnih fakultetiv do profesijnopedagogichnoyi diyalnosti v konteksti yih vokalno-metodichnogo navchannya. Socializaciya osobistosti : zb. nauk. prac T. 14. K., 2007. S. 136-142. [in Ukrainian]

3. Li Chunpen. Metodika formuvannya vokalnoyi kompetentnosti majbutnih uchiteliv muziki: dis. ... kand. ped. nauk: 13.00 .02 - teoriya i metodika muzichnogo navchannya. NPU im. M.P. Dragomanova. K., 2013. 203 s. [in Ukrainian]

4. Merezhko Yu.V. Formuvannya navichok samostijnoyi roboti majbutnih uchiteliv muzichnogo mistectva na zanyattyah z postanovki golosu. Naukovij chasopis NPU imeni M.P. Dragomanova. Seriya 14. Teoriya i metodika misteckoyi osviti : zb. nauk. prac. Vip. 26. K. : NPU im. M.P. Dragomanova, 2019. - S. 75-82. [in Ukrainian] 
5. Huan Chanhao. Specifika vokalnogo navchannya majbutnih vchiteliv muzichnogo mistectva. Naukovij chasopis NPU imeni M.P. Dragomanova. Seriya 14. Teoriya i metodika misteckoyi osviti : zb. nauk. prac. Vip. 26. K. : NPU im. M.P. Dragomanova, 2019. S. 169-175. [in Ukrainian]

6. Cin Chen. Osoblivosti formuvannya gotovnosti do samorozvitku majbutnogo uchitelya muziki u procesi vokalno-horovogo navchannya.Naukovij chasopis NPU im. M.P.Dragomanova. Seriya 14. Teoriya i metodika misteckoyi osviti : zb. nauk. prac.- Vip. 16(21). K. : NPU im. M.P. Dragomanova, 2014. S. 99-104. [in Ukrainian]

7. Yan Bohua. Muzykalnoe vospitanie v obsheobrazovatelnyh shkolah sovremennogo Kitaya : avtoref. dis. ... kand. ped. nauk : 13.00.02 - teoriya i metodika obucheniya i vospitaniya. Sankt-Peterburg, 2009. 24 s. [in Russian]

8. Yao Vej. Problemy razvitiya vokalnogo professionalnogo obrazovaniya $\mathrm{v}$ sovremennom Kitae [Elektronnyj resurs] URL: http://cyberleninka.ru/article/n/problemy-razvitiya-professionalnogo-obrazovaniav-sovremennom-kitae/ [in Russian]

About the author:

Haiye Liang, Candidate of Pedagogical Sciences (Ph.D.), lecturer, HuangGang Normal University (438000, HuangGang, Hubei, China); ORCID: 0000-0001-9944-1866, 417689733@qq.com 